\title{
The national qualifications framework and the unconstitutional limitation of academic freedom
}

\author{
R Malherbe \& S Berkhout
}

Rand Afrikaans University \& University of Pretoria

\begin{abstract}
In the rush to generate and register standards and qualifications in terms of the National Qualifications Framework (NOF) and establish bodies to assure the quality of education and training programs, little attention is being paid to the concept of academic freedom. Although access to higher education institutions sporadically feature in the public discourse, the absence of any significant reflection on the impact of the NQF on academic freedom is cause for serious concern. In this contribution we explore academic freedom as guaranteed by the Constitution and argue that academic freedom is a central feature of a university in a democratic society which should be respected by all stakeholders. After an analysis of the NQF and SAQA directives, we conclude that these initiatives limit academic freedom unconstitutionally. We conclude with some suggestions as to the principles on which the relationship between the state and the university should be founded in order to uphold academic freedom without paralysing the state's efforts to transform education for the benefit of all.
\end{abstract}

\section{INTRODUCTION}

$\mathrm{N}$ umerous steps have been taken to direct and shape transformation in education, of which the establishment of the National Qualifications Framework was one of the earliest and potentially one of the most far-reaching. In the rush to generate and register standards and qualifications and establish bodies to assure the quality of education and training programs, little attention is being paid to the concept of academic freedom. Although access to universities sporadically feature in the public discourse, the absence of any significant reflection on the impact of the NQF on academic freedom as a constitutional right is cause for serious concern.
In this contribution we argue that academic freedom is a central feature of the university in a democratic society, particularly if it wants to "... maintain its unique identity as a centre of free, independent inquiry, an agent of intellectual and cultural renewal and a stronghold of an education that furthers an inclusive, universal experience and expression of humanity" (Rossouw 1993). We explore the right to academic freedom as guaranteed in the Constitution, followed by a critical analysis of SAQA and the implications of the NQF. After applying section 36 of the Constitution, the general limitation clause, we conclude that these initiatives impose an unconstitutional limitation on the right to academic freedom. The contribution concludes with some suggestions for the principles on which the relationship between the state and universities should be founded in order to uphold academic freedom without paralysing the state's efforts to transform education for the benefit of all.

\section{THE IMPORTANCE OF ACADEMIC FREEDOM}

Academic freedom is a concept that, according to Rossouw (1998:53), becomes prominent only when it is threatened. Academic freedom and the university are such intertwined notions that it is difficult to reflect on them in an exclusive and essentialist manner. It is a foundational notion which is promoted and defended as a primary condition for the successful realisation of the university's cognitive endeavour. It is a concept that usually becomes relevant in an invasive political environment of which McCarthianism in the USA, the Nazi-period in Germany, and the apartheid era in South Africa should serve as grim reminders.

Academic freedom has again become threatened. First, the effects of globalisation and information and interactive technology are posing serious challenges to universities and the traditional ways of going about their "business". The fluidity of disciplinary boundaries in an era in which the development of new areas of knowledge demand a hearing, and unabashedly 
borrow from but also contribute to older subject areas does not make educational choices any easier (Browning, Halcli \& Webster 2000:2). In this situation academic freedom seems to have lost its relevance. Secondly, academic freedom is under threat, not as a result of political encroachment, but in the more insidious way in which the concept is excluded from a debate that focuses on the crisis of the survival of universities. Economic competitiveness and "performativity" (Webster 2000) have become the prominent notions that shape the public discourse on higher education.

For Rossouw (1998:53) freedom is a concept that includes, on the one hand, not being obstructed in an endeavour and, on the other hand, having the means to successfully realise set goals. Academic freedom is part of an institutionalised lifestyle in which the boundaries of understanding and conceptual frameworks are continuously and critically tested and shifted. From the earliest times when lectio and disputatio constituted the basis of an academic practise that deemed itself accountable only to the unbiased and objective search for the truth (Olivier 2000), academic freedom has been foundational to the raison d'etre of universities. It constituted one of the founding principles of the Von Humboldt University. Philosophers like Schelling went so far as to argue that the ability to truth is founded in freedom (Ijsseling 2000). Indeed even the universalistic and objective views of science that resulted in the dominance of the natural sciences and their rationalist assumptions and powerful technologies developed within a context of conjectures and refutations (Popper 1974) of a continuous testing and re-testing of shifting boundaries and paradigms. Popper (ibid 352) argues that truth is not easy to discover and it demands at least imagination, trial and error, and the gradual discovery of our prejudices by imaging, testing and critical discussion.

In a late- or post-modernist period of ambivalence and dichotomous views, the importance of academic freedom needs to be reinforced rather than neglected. In the "risk society" of Beck (1993:235) where new forms of marginalisation are taking shape, one of the consequences becomes an imperative to "... engage in controversial and alternative discussions on the risks of certain steps and plans in advance, and not only in intra-disciplinary circles but also in interdisciplinary partial public spheres that would need to be created institutionally". Historically, universities are such special institutions where the learning processes of the academic community have through centuries gained and retained the trust and recognition of society (Rossouw 1998:53). In this context, subsidisation of higher education by the state is not inconsistent with academic freedom; it illustrates, as a matter of fact, that academic freedom is pursued with society's blessing.
In South Africa, where transformation should include an endeavour not only to access and use available information, but also to build an indigenous knowledge base (North 2000), the freedom of universities will be shackled at great risk to quality higher education as well as to our fledgling democracy.

We live in a "real world" that manifests a degree of uncertainty and fluidity, matching the "fuzziness" of theory. The importance of an unfettered, continuous testing of the boundaries of our understanding and the social and moral implications thereof and, concomitantly, of what and how it gets taught should have society's unequivocal commitment and support. Fortunately, academic freedom has been regarded important enough in South African society to be constitutionally guaranteed.

\section{THE RIGHT TO ACADEMIC FREEDOM}

\section{Academic freedom is guaranteed in the Constitution}

Section 16(1)(d) of the Constitution provides that everyone has the right to freedom of expression, which includes academic freedom and freedom of scientific research. From the point of view of universities, the inclusion of a right to academic freedom, first in section 14 of the interim Constitution, and now in the 1996 Constitution, has been a major step forward (Malherbe 1995; Du Plessis \& Corder 1994). The Constitution is the supreme law and all laws and government actions are subject to it. Academic freedom is thus a value which forms part of our supreme law. We regard this as a recognition of the academic freedom of individual lecturers, as well as the institutional autonomy of universities. As a matter of fact, section $16(1)(d)$ is a constitutional recognition of the unique position of universities in democratic societies.

Academic freedom refers to the freedom of everybody engaged in the practice of science to teach and do research as they deem fit and without interference (Malherbe 1993a). Rossouw (1998) refers to their intellectual autonomy. Actually, the first attempt to a legal definition of academic freedom was made by South African academics in the fifties in reaction to government interference. They defined academic freedom as the right of a university "to determine for itself on academic grounds who may teach, what may be taught, how it shall be taught, and who may be admitted to study" (Smith 1995). This definition was made famous in 1957 when Judge Frankfurter incorporated it into American law in Sweezy $v$ New Hampshire. It also clearly points to the collective or institutional element of academic freedom, which we prefer to call university autonomy. Obviously, decisions as to who may teach and who may be admitted to study should be taken by the institution and not by 
individual academics. Academic freedom is not recognised expressly in the American Constitution and has been derived by the courts from the right to freedom of expression. The German Constitution does not employ the term "academic freedom" and refers to the freedom to practise science (Jarass \& Pieroth 1996)

Academic freedom belongs to everyone engaged in the practice of science and lecturers, students and members of research institutions alike may therefore claim the right to academic freedom. With regard to the interests and conduct protected by academic freedom, it must be emphasised that the right has more to it than mere freedom of expression. As a matter of fact, academic freedom is sometimes described as a composite term for a number of other rights like freedom of expression, freedom of conscience, thought, belief and opinion, freedom of association and vocational freedom (Bray 1993). The inclusion of academic freedom under freedom of expression is thus somewhat unfortunate, as it does not reflect the full scope of the right. In addition to these other rights, the content of academic freedom can be summarised as follows:

- Freedom to teach without outside interference: It includes the content and process or methodology of teaching, as well as the evaluation or examination of those taught (Maunz-Dürig 1991). Who are allowed to study and the maintenance of standards are obvious corollaries of this freedom.

- Freedom to do research without outside interference: Research has been described by the German Federal Constitutional Court as "a serious and systematic attempt in terms of content and form to find the truth" (Malherbe 1993a), and includes all research related activities, including preparatory, management and supporting actions, but not political actions or actions on which outside principals exercise decisive influence. Obviously, it includes the dissemination of results through publication, etc.

- Compliance with professional and ethical norms and peer evaluation according to academic criteria: This refers to the right to be assessed by one's peers and not by outsiders.

- The right to tenure: Once an academic complies with reasonable criteria and has secured a permanent position, she enjoys all its benefits, including representation in university structures, and may hold office until retirement (Bray 1993). This includes the right to form and express academic opinions without fear of retribution affecting her tenure.

The state has a constitutional obligation to recognise and protect these rights, inter alia by refraining from undue interference in the affairs of academics. Of course, the university has a similar duty in respect of its teaching staff. Any infringement must comply with the provisions of the general limitation clause and must be reasonable and justifiable in an open and democratic society based on human dignity, equality and freedom (section 36). In terms of its duty to respect, protect, promote and fulfil the right (section $7(2))$, the state is obliged to provide the necessary financial and organisational assistance required for the enjoyment of the right (Maunz-Dürig 1991). The state thus has a supporting role in the exercise of academic freedom.

\section{Academic freedom includes the autonomy of universities}

\section{The university}

The idea of the university is an elusive one, but for our purposes it is a statutory institution of higher education directed at the generation and transmission of knowledge through teaching and research and the training of students for certain professions that require advanced knowledge (Dlamini 1996). Some legal characteristics of the university can be mentioned briefly.

(a) The university is a "juristic person". The university is recognised in law as a separate entity that acts in its own name. Most importantly, as a juristic person the university is subject to the law.

(b) The university is a "statutory institution". All universities in South Africa have been established in terms of parliamentary legislation and currently all are governed by the Higher Education Act. Universities own their existence to the state and, formally, the state exercises control over them.

(c) The university is an "institution of higher learning through teaching and research". Universities stand at the "pinnacle of the country's education system" (Kriel 1982). Due to the recognition of academic freedom, the university has in fact acquired a unique position in society in terms of which it enjoys some measure of autonomy vis$\grave{a}$-vis the state (Bray 1993). However, it goes without saying that the university is not an ivory tower; it exists to serve society and its autonomy is recognised for that purpose (Bok 1982).

(d) In terms of the Constitution (section 239), the university is an "organ of state" (Pienaar 1997). It functions in terms of legislation and it performs a public function, the provision of education. (Private universities, on the other hand, do not function in terms of legislation and are accordingly not organs of state - Malherbe 1999b.)

(e) As an organ of state, the university is "bound by the Bill of Rights" (section 8(1)). The university must respect and protect the rights of its staff and students and of the public at large. Any limitation imposed by the university on anybody's rights must comply with the general limitation clause in the Bill of Rights (section 36). 
(f) The university is in the unique position that it is also a "bearer of rights in the Bill of Rights". A juristic person is entitled to rights to the extent that the nature of the rights and of the juristic person so requires (section 8(4)). Academic freedom is one of the most obvious rights which the university may claim against the state, but there are probably other rights as well (Malherbe 1999b).

\section{University autonomy}

University autonomy refers to the self-governing power of the university to decide independently on academic-related matters (Malherbe 1993a). Rossouw (1998) refers to the self-regulatory authority of the university. This autonomy is obviously not unlimited and is restricted to matters related to the achievement of the university's mission as an institution aimed at teaching and research (Tasker \& Packham 1990; Bray 1993). In the USA, autonomy, or institutional academic freedom (Finkin 1983), has developed out of academic freedom, whereas in Germany, autonomy has been recognised alongside academic freedom on the basis of section 5(3) of the Constitution which provides that art and science, research and teaching are free (Naumann \& Krais (1991).

One could argue that university autonomy is merely the collective exercise of academic freedom. Indeed, the individual lecturer exercises her academic freedom within the university milieu and the university provides essential shelter to academics. Put differently, the university is the institutional form in which the practice of academic freedom is formally recognised by society (Rossouw 1998). As pointed out below, the content of the concepts nevertheless differ. More important, though, is the fact that the concepts go hand in hand. They are mutually supportive and both should be promoted for one to flourish (Bessant 1982; Tight 1988).

For these reasons, and in line with the position elsewhere, it is appropriate and essential to include university autonomy under academic freedom in section $16(1)(d)$. As stated above, by its very nature and by the nature of the university as a juristic person, academic freedom is one of those rights to which the university can lay claim. What we do submit is that the content of the academic freedom of the university and of the individual differs. Autonomy obviously includes matters not applicable to the academic freedom of the individual lecturer. The conduct and interests of universities protected by the right to academic freedom can accordingly be summarised as follows (Malherbe 1993a):

- Appointments in the highest governing body of the university. As a societal institution partly depen- dent on public funds, the community and the state are represented in this body (Bray 1993).

- Adoption of an institutional statute and regulations, subject to the governing legislation and ministerial approval.

- Composition of academic structures of the university.

- Determination of teaching and research priorities. Although influenced by financial considerations and the priorities of the public and private sectors, which subsidise or sponsor research, the actual determination of priorities should remain in the hands of the university.

- Raising and utilisation of funds and the allocation of approved public funds in accordance with reasonable conditions imposed by the state.

- Appointment, conditions of service, remuneration, promotion and dismissal of academic and other staff. This is balanced by the individual lecturer's right to tenure (see eg Yates $v$ University of Bophuthatswana).

- Admission requirements and the selection, admission and re-admission of students and the termination of their registration. Bound by the bill of rights, a university must comply, for example, with the rules of natural justice when it takes decisions in this regard (see eg Lunt $v$ University of Cape Town).

- Disciplinary measures and procedures applicable to students and staff (Durr v Universiteit van Stellenbosch).

- Institution of faculties, departments, degrees, courses and diplomas, with ministerial approval.

- Institution of certificates.

- Determination of the content of curricula.

- Examinations for and the conferral of degrees, diplomas and certificates.

- Internal management and administration.

- Where applicable, determination of the medium of instruction.

These powers and functions are exercised subject to the law in general and the Constitution in particular. Inter alia, the university must act within the parameters of the Higher Education Act and whenever it violates the rights of anybody, its actions are invalid unless they comply with the limitation provisions in the Constitution. For our purposes, it is important to note that any limitations the state may impose on the autonomy of the university through legislative or other actions such as the Higher Education Act or the South African Qualifications Authority Act are equally subject to the constitutional limitation provisions. 


\section{SOME CONSEQUENCES OF THE NOF AND} SAQA

\section{The McDonaldization (Ritzer) of South African universities}

The South African Qualifications Authority is responsible for the development and implementation of an integrated national framework of study achievements and to facilitate access, mobility and progression in education, training and career paths. Apart from this responsibility, which has impacted rather forcefully on the activities of universities which have had to reformat their qualifications and standards for interim registration by the end of June 2000, SAQA also has the responsibility to enhance the quality of education and training and to accelerate the redress of past unfair discrimination in education, training and employment opportunities. For the purpose of realising its objectives, SAQA has established National Standards Bodies (NSB's) to oversee the standard generating and evaluation functions and is in the process of instituting Education and Training Quality Assurance Bodies (ETQA's) to assure the quality of all education providers according to either education band or social and economic sectors. The Higher Education Quality Committee (HEQC) is the body responsible for quality in the higher education band. This process must result in a National Qualifications Framework that reflects various standardised pathways of "... achievement of the required number and range of credits and such other requirements at specific levels of the NQF" according to the "... registered statements of desired outcomes and their associated assessment criteria" (RSA 1995 section 1).

This development should enable the central management and funding of a national higher education system (cf the Higher Education Act and the powers of the Minister of Education). Instead of being autonomous universities determining what and how to teach, to whom and by whom, they run the risk of being reduced to "agents" bidding for the right (funding) to provide programs leading up to nationally registered qualifications or standards, or "ennobled trade schools" (Wielemans 2000). This could metaphorically be compared to the way in which franchisee organisations such as McDonald's function (Ritzer 1998). Apart from centralised planning of standards with regard to the product, control is exercised to assure the quality and standardisation of outlets and service. This kind of planning is aimed at satisfying customer needs and though confined and focussed, far more effective and cost-efficient than traditional consumer outlets. After having generated and set standards and qualifications, SAQA could be seen to become the franchisee of education, training and career paths by accrediting education providers to offer quality assured programs that will lead up to the SAQA trademarked qualification and/or standard. This should assure qualified persons with an outcomes-based standardised and assessed product specification for the occupational market.

When read in conjunction with the Minister of Education's power to fund education programmes, the implications for academic freedom becomes even more serious. Not only will the "what" and "how" of teaching become standardised via the SAQA process, but the Minister of Education will have the power to decide how many student places at a particular institution in a particular program to fund. This would most probably assure greater cost-efficiency of the higher education system. It might also assure a better fit between manpower needs and education, but it most definitely will not be supportive of academic freedom. In a context where most students want little more than "... simple procedures, good service, quality courses, and low costs (and a good job thrown in) ... and to which they bring the same consumer expectations that they have for every other commercial enterprise with which they deal" (Levine as quoted by Ritzer 1998:153), it is most unlikely that the arduous process of critical reflection and debate would be considered desirable consumption. Apart from the direct threat to their resource base, this could also constitute an infringement on universities' endeavour to reach their academic goals.

\section{Organising fields occupationally delineated}

The restructuring of historically developed, ceaselessly contested bodies of knowledge or disciplines into twelve organising fields (and a number of subfields) is based on the assumption that the structure of knowledge is a social construct - an assumption with which we can concur. What raises questions, though, is the deduction that this implies the possibility of restructuring knowledge via a stakeholder representative mode - on the one hand, implying that knowledge can best be served by a democratic process and, on the other, that it is a rational and engineerable process.

As has been indicated earlier, in late- or postmodernist societies the boundaries of knowledge have become increasingly permeable, fluid, ambivalent and dichotomous. It could, however, still be argued that underpinning the raison d'etre of universities are universally acknowledged bodies of knowledge that constitute the content and discipline of what gets taught and how - an archaeology of knowledge (Foucault 1970), that had its origin in the notion of academic freedom as institutionalised within the context of universities. Notwithstanding the variety of interpretations of the notion of freedom in science, it can generally be associated with an openminded search for the truth. This development and growth has always been within, and because of, the contestation and refutation of understanding - from 
the fertile doubt that results from lingering within the margins of institutionalised texts (Derrida as cited by Ijseling 2000). This presupposes a critical attitude that does not allow for the reduction of everything to representations and ultimately to consumable objects (Goosen 2000). The question obviously arises as to whether academic freedom could survive within a context of occupationally delineated fields of knowledge.

The delineation of the NQF into twelve organising fields (and a number of agreed upon sub-fields) and eight levels of complexity is presumably based on the assumption that the transformation of education in South Africa will best be served by the restructuring of the knowledge structure to serve economic needs. Although university qualifications can empirically be linked to successful participation in a productive context, it is doubtful whether this can inevitably be ascribed to occupationally derived competencies or outcomes. The technical committee on higher education (as cited in Ogunrondi 1994:16) for one, has argued that the discursive mode of traditional higher education concerned with the skill of mastering the intellectual requirements of disciplines, involving familiarisation with a diverse range of discourses, explanations and discipline-specific procedures does not "... sit easily with a competency approach emphasising end-stopping and measurable outcomes".

The process of delineation of knowledge for registering standards has become one in which the dominant role-players are business and labour representatives probably to reclaim part of the levy on their employment remuneration bill (cf the Skills Development Act 1999). This could increasingly result in setting boundaries and registering standards and qualifications that serve the needs of employers. It is open to question how much space that will leave for critical and creative reflexive practices so inherently part of academic freedom. The instrumentality of such an approach will leave universities little scope for choice with regard to what they teach. They will become snared into the short-term allure of enticing students who are set to gain measurable workplace related skills.

\section{Democratic standardisation bureaucratically controlled}

Notwithstanding the questions that could be raised with regard to the impact of stakeholder representation on the knowledge delineation process and whether this would serve the search for the truth, what is relevant within this context is the minimalised role ascribed to academic expertise. Universities are allowed one representative on the SAQA itself (consisting of 36 members). On the NSB's, which have to do the actual work to delineate and evaluate and recommend standards and qualifications for registration, the universities are allowed a single representative as a provider, whereas labour, business and the state each are allowed up to six representatives. Will a body thus constituted be able to evaluate qualifications for registration and recommendation on the higher levels of the NQF where their own qualifications seldom feature? How will provision be made for the progressive development of competencies within particular fields of expertise? This might be one of the reasons why reference to a required number of credits can be found in the SAQA legislation and regulations, whereas agreement has not yet been reached on the so-called level descriptors.

This process will, however, undoubtedly impact on the choice available to universities with regard to what and how they teach. The initial process of interim registration requires universities to submit their existing qualifications in a reformatted way. It is, however, anticipated that all standards and qualifications will eventually have to follow a process of public scrutiny (eg via the SGB's) when qualifications and standards will become part of the public domain. Thus, all qualifications will be SAQA franchised.

There is, of course, an argument that an outcomesbased approach leaves scope for providers to develop their own programs (or the "what" and "how" of education). This could be why universities are compliantly following the SAQA requirements for the registration of their qualifications. The other leg responsible for the assurance of quality has not yet made its impact felt. A body that has the power to accredit providers to offer particular programs and register assessors must eventually also influence what and how universities fulfil their educational function. The HEQC will advise the Minister on the value of particular programs, enabling him to take decisions with regard to funding. This could lead to quality assurance becoming prescriptive rather than merely advisory and evaluative.

The arduous process of calibrating all qualifications will eventually have to be completed with qualifications and standards defined and registered with a bureaucracy to implement it according to the regulations. The question may be asked whether it will then become possible for the Minister of Education to request from universities, as merely another agent providing higher education, to tender for funding for programs according to national priorities.

The above systemic interpretation of the impact of SAQA on academic freedom will now be followed by a brief juridical analysis, particularly with regard to the constitutional implications of the format in which qualifications are to be registered. 


\section{THE UNCONSTITUTIONAL LIMITATION OF ACADEMIC FREEDOM}

\section{The NQF limits academic freedom}

We want to argue that the way the NQF is taking shape will unconstitutionally limit academic freedom to the detriment of higher education in particular and a democratic South Africa in general. This issue is explored below with reference to the essence of academic freedom as explained above, viz. the "what", the "how", the "by whom", and the "to whom" of the teaching component of the right.

\section{The what of teaching}

SAQA requires that a qualification (and eventually every module) be registered in a standardised format. This cannot but impose limitations on the autonomy of universities with regard to "what" they teach. Although it is alleged that the rethinking of academic qualifications in terms of outcomes is a meaningful reflexive process, it is still a prescriptive way of organising what gets taught or, now called, learned. The information required by the prescribed format will probably have a number of effects:

(a) It first of all requires a descriptive purpose that is unique and formulated in accessible language. Although academic outcomes related to mastering a particular discipline are not excluded, purposes need to be formulated in terms of "what the learner will know and be able to do on the achievement of the qualification", which implies an occupational focus that will of necessity impact on academic disciplines and what gets taught - for example, to prepare the learner to "... practise as a ... within a particular context". This notion already runs contrary to the more abstract conception of knowledge taught at universities and will most probably limit their choice.

(b) The qualification specification also needs to be in accordance with SAQA's directives on what constitutes a diploma, degree, etc on a particular level and must accordingly reflect the number of prescribed credits (level descriptors that leave some freedom of choice are still being debated). Motivation for what is included or excluded and the particular combination of fundamental, core and elective modules should also be included. As far as credits are concerned, there is a directive on fundamentals to be taught in all programmes on particular levels of the NQF. Whether this is good or bad is not the argument; it does, however, constitute a prescription of what should be taught, as well as limits the number of credits available for teaching more discipline-related skills or knowledge. It can be assumed that the number of credits allocated to each of the learning components should be appropriate in terms of the definitions and the extent to which they might, in combination, be supposed to achieve the purpose of the qualification. Evaluating this implies a fairly serious infringement on the judgment of the universities to choose what and how they teach.

(c) All qualifications must be classified within the boundaries of a field or delineated sub-field. This implies a restriction with regard to the classification and selection of knowledge to be taught to what has been agreed upon by the NSB's, usually on an occupational basis (as explained above). It seems as if this approach excludes disciplines or courses that somehow cannot be positioned within the boundaries of any of the identified fields.

(d) Learning assumed to be in place clearly refers to content, and also to who are admitted to study. The need for capturing field-relevant competencies for achievement within the parameters of the particular qualification (field or sub-field) implies a fundamental shift in terms of universities' access criteria (the "whom" should be taught). Within the context of the "what" should be taught, it can, however, be assumed that to enable progression and articulation this will have to be fairly standardised and comparable which would again be restrictive.

(e) All qualifications and standards must reflect exitlevel outcomes that include certain critical crossfield outcomes. A qualification or module need not reflect all twelve outcomes, but obviously as many as possible should be included in order to satisfy SAQA that the qualification/module is relevant in terms of outcomes-based education. It seems as if very few qualifications/modules reflect all or even a sufficient number of the outcomes. (Examples of outcomes which are not normally reflected as such in academic courses, are teamwork, technological and environmental literacy, cultural and aesthetic understanding, citizenship, employment seeking skills and entrepreneurial skills.) The outcomes are very specific and an indication that they receive indirect attention will probably not suffice, especially since measurability and verifiability are usually required with regard to assessment criteria and practices.

(f) Integrated assessment will have to be appropriately incorporated in order to ensure that the purpose of the qualification is achieved. This assumes a logically consistent or empirically verifiable linkage that is one of the fantasies of educational sciences. It could, however, within the context of the occupational approach, be indicative of a need for the integrated demonstration of performance within a particular context that could become highly prescriptive.

It can be concluded in this regard that outcomesbased education, with its strong emphasis on prac- 
tical training and skills, has drastic implications for academic disciplines in which the focus is more on knowledge than on skills. The end result may even be that qualifications/modules that are not sufficiently outcomes-directed will simply have to be abandoned. In short, in order to comply with the SAQA directives, the content of most qualifications/modules will have to be revised - in some cases drastically.

\section{The how of teaching}

The assumed linkage between the purpose, exit-level outcomes and assessment requirements will affect the way in which teaching or learning are planned and facilitated (or the program leading to the qualification). Some outcomes are, for example, aimed at the development of teamwork and practical and vocational skills, and the development of community awareness. Many qualifications do not address such outcomes directly. In order to reflect these outcomes, the presentation of many qualifications/modules will have to be adapted quite comprehensively, even if the content, despite the above remarks, remain the same. Furthermore, the SAQA directives imply that existing assessment criteria and methods will have to be revised in order to provide for the assessment of the stated outcomes for every qualification/module. When the HEQC becomes fully operational it can be expected that programs and assessment (or the "how" of teaching) will be scrutinised and regulated much more closely than will be conducive to upholding academic freedom.

\section{The by whom of teaching}

As explained, the principle of peer evaluation lies at the root of the question who teaches. Quality assurance as envisaged by SAQA has serious implications for this principle. As mentioned, extensive provision is made for a plethora of standard generating and quality assurance bodies. Universities have only one representative in each of these SGB's and ETQA's. The inevitable effect will be that quality assurance is taken over by the state, that peer evaluation no longer forms the basis of the assessment of academic staff, and that the university's autonomy to determine who will teach is seriously undermined. A request has already been made for information on the staff responsible for developing and teaching qualifications.

\section{The to whom of teaching}

This refers to the admission, evaluation, selection and promotion of students, for which the NQF has definite implications. The recognition of prior learning, the acquisition of credits that can be transferred from one educational institution to another, and the introduc- tion of multiple entry and exit points in a qualification are all mechanisms that deeply affect the admission policies of universities. It will not be possible for a university to impose admission policies that disregard these mechanisms.

The SAQA requirements also affect the autonomy of a university to decide who can be promoted and be awarded a qualification. For example, if the system of credits is implemented consistently, it would seem untenable for any university to continue a policy of awarding a qualification only if at least half the courses for that qualification has been obtained at that university.

In effect then, a university forfeits its control over who is admitted to learn and to whom qualifications are awarded. In this way, a university will lose its capacity to determine standards and to fill a unique niche in higher education.

\section{Conclusion}

The conclusion is inevitable that the NQF, including the SAQA requirements for the registration of qualifications/modules, limits the teaching component of the constitutional right to academic freedom.

\section{Is the limitation of academic freedom constitutional?}

No right is absolute. Academic freedom may also be limited lawfully for the promotion of a legitimate common interest. Academic freedom should, for example, be tempered by the need for public accountability. In view of our conclusion that academic freedom is indeed limited by the NOF and the SAOA requirements, the next question is whether the limitation is constitutional.

Section 36(1) of the Constitution provides that a constitutional right may be limited in terms of a law of general application only if it is reasonable and justifiable in an open and democratic society based on human dignity, equality and freedom. In order to determine whether a limitation is reasonable and justifiable, the following factors must be considered: (a) the nature of the right; (b) the importance of the purpose of the limitation; (c) the nature and the extent of the limitation; (d) the relationship between the limitation and its purpose; and (e) less restrictive means to achieve the purpose. These factors are aimed at determining whether a balance exists between the limitation and its purpose which is reasonable and justifiable in an open and democratic society.

In order to determine whether the limitation which the NQF imposes on academic freedom is constitutional, 
section 36 must be applied. In broad terms, this enquiry may run as follows (see eg Rautenbach \& Malherbe (1999):

\section{The nature of the right}

The nature of the right gives an indication of the kind of purpose that can justify the limitation: the more important the right, the more important the purpose of the limitation must be to be justified. In an open and democratic society based on human dignity, equality and freedom academic freedom must be regarded as an important right. The right goes hand in hand with other freedom rights such as freedom of expression (as a matter of fact, academic freedom has been included in section 16, which guarantees the right to freedom of expression), the right to freedom of conscience, thought, religion, belief and opinion (section 15), the right to assemble (section 17), the right to freedom of association (section 18) and occupational freedom (section 22). Some even argue that academic freedom is a combination of all these freedom rights (Bray 1993). Also significant is that in the United States academic freedom has been inferred from freedom of expression. In short, a democracy without academic freedom is unthinkable and any limitation of the right should be tolerated only for a very compelling public purpose.

\section{The importance of the purpose of the limitation}

The question here is whether the purpose of the limitation is important enough to accept that it is reasonable and justifiable in an open and democratic society. Normally, it concerns the protection or promotion of a particular common interest. In terms of the South African Qualifications Authority Act, 1995, the purpose of the NQF is to create an integrated national framework for study performance; promote access to and progression within education; improve quality; redress historical discrimination; and assist in everybody's development. These are laudable objectives but, in the final analysis, it is a matter of opinion whether the system will, in fact, produce these results. It cannot be "proved" easily. There is enough debate on this among educators to warrant a conclusion that there are probably as many arguments against as for the system. In the countries in which the system is applied to our knowledge, it is not enforced on a national basis, and in any case not to higher education. This puts the purpose of the limitation of academic freedom under a measure of doubt. The point is that the importance of the purpose of the limitation must contribute to the justification of the limitation, and if its importance is not fully apparent, it can hardly justify the limitation.

\section{The nature and extent of the limitation}

The question of how the right is limited and which effect the limitation has on the right assists in determining whether a balance exists between the limitation and its purpose that is reasonable and justifiable in an open and democratic society. This involves various considerations. It is evident from the above remarks that the content of academic freedom is limited and will be even more drastically limited in a future centrally controlled higher education system. The essential elements of the teaching component of academic freedom, viz. the "what", the "how", the "by whom", and the "to whom" of teaching are affected directly and will become even more so.

Furthermore, these elements are limited so severely that little scope remains for the exercise of the right. It should be borne in mind that the SAQA directives are not mere guidelines; they are applied in great detail to every qualification/module. Another consideration is that we have reached only the stage of interim registration. A comprehensive public process for the purposes of final registration still lies ahead. Finally, as explained above, the statutory quality assurance mechanisms that are envisaged will also affect academic freedom directly. Briefly put, a strong argument could be advanced that the drastic limitation of academic freedom which these considerations reveal is not commensurate with the stated purpose and cannot be justified in an open and democratic society.

\section{The relationship between the limitation and its purpose}

The limitation must indeed promote the purpose and in a rational way, otherwise the limitation is not reasonable and justifiable in an open and democratic society. The NQF is essentially untested and it cannot be determined with even some measure of certainty whether the limitation of academic freedom will indeed promote the purpose. This obstacle in itself points to serious doubt whether a rational relationship exists between the limitation and its purpose. In addition, a limitation may be excessive or overinclusive. Even if it is accepted that the limitation indeed promotes the purpose, it must be taken into consideration that the limitation is certainly drastic or excessive as explained above, also indicating an absence of a rational relationship between the limitation and its purpose.

\section{Less restrictive means to achieve the purpose}

Finally, it must be established that alternative ways were considered that would limit the right less drastically, but would promote the purpose more or less equally effective. This is necessary to assist in 
establishing a rational relationship between the limitation and its purpose. First, in this regard, the drastic nature of the limitation on the content of academic freedom must be emphasised. Secondly, it must be realised that the directives are enforced in all respects by legislation. There is no room for individual academics or universities to employ other mechanisms or exercise other choices - they are simply bound by the legislation. Merely in principle, therefore, the fact that the system is enforced by law is in the context of academic freedom an indication that the less restrictive means has not been elected to pursue the objective.

Less restrictive means are indeed available. First, instead of the overwhelmingly detailed directives, broad, but enforceable, guidelines could have been provided for universities to elaborate on and develop a quality assurance system themselves. That would have softened the drastic infringement of the substance of academic freedom. Secondly, and that would have been the preferable choice, the government could have entered into negotiations with the universities to convince them to adopt and implement the system voluntarily. The publication for comment of white papers, draft legislation and bills does not amount to negotiation, because throughout that process the objective remained the enactment of binding legislation. Rather in this context, negotiation would mean a recognition and acceptance of academic freedom and the adoption of an approach in terms of which universities were allowed to implement the system by themselves. (This is, for example, the approach that is being followed successfully in the Netherlands.)

\section{CONCLUSION}

When all the above factors are weighed, the conclusion is inevitable that the limitation which the NQF, including the SAQA directives for the registration of qualifications and modules, and the quality assurance mechanisms, impose on academic freedom as guaranteed in section 16(1)(d) of the Constitution cannot be justified in terms of section 36, and that it is therefore unconstitutional.

\section{WHAT NOW?}

Academic freedom is not a static concept and should keep up with developments, needs and tendencies in society. A core remains, however, which needs to be cherished with great care - not only for the sake of the freedom necessary to practice science, but for the sake of a democratic society itself, which is always tempted to become entangled in short-term issues and priorities. The purpose of academic freedom is not to isolate the university from societal issues and challenges, nor to perpetuate the inequalities and injustices of the past. The university is closely involved in and committed to the creation of a just and better society. In order for the university to fulfil this role, however, the rules of the game must be respected.

First, all stakeholders should recognise that academic freedom has become a constitutional concept, which has placed the relationship between the state and the university on a firm legal foundation that should be respected by everybody. Academic freedom cannot be disposed of by a mere reference in a White Paper or the Preamble to the Higher Education Act. The Constitution requires that it be respected, protected, promoted and fulfilled in all the activities of the state.

Secondly, the university and individual academics must continue to test the frontiers of knowledge and the state must allow the university full freedom to pursue scholarship and advance all forms of knowledge. The contribution of the university is the promotion of all forms of knowledge and that, in the final analysis, is the only way in which the university can fulfil its obligation towards society.

Thirdly, the state and the university should both appreciate their respective roles and status in an open and democratic society. Both serve society and their relationship should be characterised by partnership and co-operation, and not unilateral or prescriptive action by any party.

Talks on the implementation of the NQF in higher education conducted on this basis surely promises mutual benefit. It should never be too late in an open and democratic society to re-open a matter and conduct it in a more appropriate way. Only if we respect the rules of the game, we shall be able to honour Hennie Rossouw's confidence that the university will be able to "... maintain its unique identity as a centre of free, independent inquiry, an agent of intellectual and cultural renewal and a stronghold of an education that furthers an inclusive, universal experience and expression of humanity" (Rossouw 1993) 


\section{REFERENCES}

Beck, U 1992. Risk society. Towards a new modernity. Translated by Mark Ritter. London: Sage.

Berkhout, Sarie J 1999. Die nasionale kwalifikasieraamwerk: toekoms-uitdagings vir onderwysleiers in SuidAfrika. Paper read at the annual Headmaster Simposium of the SAOU. Port Elizabeth, September.

Berkhout, Sarie J 2000. Die ontwikkeling van standaarde en die versekering van kwaliteit vir verdere onderwys en opleiding. Paper read at FEDSAS Seminar, Bloemfontein 4 March.

Berkhout, Sarie J 2000. The education qualification and the occupational structures of national states in a global market: a conceptual and comparative exploration of the development of the South African national qualification structure. Paper read at the Comparative International Society Annual Meeting. San Antonio, 8-12 March.

Browning, G, Halcli, A \& Webster, F 2000. Theory, theorists and themes: a user's guide to understanding the present, in Browning, G, Halcli, A \& Webster, F (eds) Understanding contemporary society. Theories of the present. Great Britain: Cromwell Press, Trowbridge:312-327.

Bessant, D nd. The erosion of university autonomy in Australia. Vestes 32.

Bok, W 1982. Beyond the ivory tower: social responsibilities of the modern university.

Bray, W 1993. The legal status of the South African university. LLD thesis. Unisa.

De Groof, J, Neave, G \& Svec, J 1998. Democracy and governance in higher education.

Dlamini, C R M 1996. University autonomy and academic freedom in South Africa. LLD thesis. Unisa.

Du Plessis, L M \& Corder, H nd. Understanding South Africa's transitional Bill of Rights Juta: Cape Town.

Finkin, C 1983. On institutional academic freedom. Texas Law Review 871.

Jarass, H D \& Pieroth, P 1996. Grundgesetz für die Bundesrepublik Deutschland.

Foucault, M 1994. The order of things. An archaeology of the human sciences. London: Routledge. First published in French in1966 and translated in 1970.

Goosen, D 2000. Die post-moderne universiteit: enkele spekulatiewe notas. Fragmente 5:21-30.

ljsseling, S 2000. Filosofie, politiek en universiteit Fragmente 5:11-20.

Kriel, J, 1982. A university on African soil - towards a definition of goals, in Thembela (ed) Proceedings of a Symposium. University of Zululand, September 1982.

Malherbe, E F J 1993a. Die regsbeskerming van akademiese vryheid en universiteitsoutonomie in 'n nuwe SuidAfrika. TSAR 359.

Malherbe, E F J 1993b. 'n Handves van regte en onderwys. TSAR 686.

Malherbe, E F J 1996. Die onderwysbepalings van die 1993 Grondwet. 1995 TSAR 1.

Malherbe, E F J 1999a. The impact of the constitution on higher education in South Africa, in De Groof, J, Legotlo, W. Potgieter, J \& Malherbe, R (eds) Promoting a human rights culture in education: responsibilities and opportunities in a transforming society. Mijs and Breesch: Gent 241.

Malherbe, E F J 1999b. A constitutional perspective on higher education in South Africa. Stellenbosch Law Review 328.

Naumann, W \& Krais, P 1991. German Federal Republic, in Altbach (ed) International higher education: an encyclopedia 688.

Ogunronbi, S 1998. The application of the outcomes based education (OBE) orthodoxy in legal education and its foundational limitations. Department of Commercial Law, Vista University.

Olivier, F 2000. Ja maar wat is die universiteit? Fragmente 5:41-46.

Pienaar, G 1997. Regsubjektiwiteit en die regspersoon. University of Potchefstroom.

Rautenbach, I M \& Malherbe, E F J 1999. Constitutional law. Butterworths: Durban.

Popper, K R 1974. Conjectures and refutation. The growth of scientific knowledge. London: Routledge and Kegan Paul.

Rossouw, H J 1993. Universiteit, wetenskap en kultuur. Tafelberg: Kaapstad.

Rossouw, H J 1998. Die begrip akademiese vryheid. Lecture to the Department of Philosophy, RAU, Johannesburg.

RSA 1995. South African Qualifications Authority Act 58 of 1995. Cape Town.

RSA 1997. Higher Education Act 101 of 1997.

RSA 1999. Skills Development Act no ///.

SAQA 1999. Criteria for the generation and evaluation of qualifications and standards within the national qualifications framework. Draft 3.

SAQA 2000. Criteria and guidelines for ETQA accreditation of providers. Draft for public comment.

SAQA 2000. Criteria and guidelines for ETQA's. Public Document.

SAQA 2000. NSB treatment of qualifications and standards received via different routes. Division of Standard Setting Draft Document. 16 February.

Smith, N 1995. Constitutional academic freedom. SALJ 678. 
Tasker, J \& Packham, D 1990. Freedom, funding and the future of the universities. Studies in Higher Education 182.

Tight, $\mathrm{H}$ 1988. So what is academic freedom? in Tight, $\mathrm{H}$ (ed) Academic freedom and responsibility 132.

Venter, F 1995. Die staat en die universiteitswese in Suid-Afrika: nuwe wedersydse grondwetlike verantwoordelikhede, regte en verpligtinge. THRHR 379.

Webster, F 2000. Higher education, in Browning, G, Halcli, A \& Webster, F (eds) Understanding contemporary society. Theories of the present. Great Britain: Cromwell Press, Trowbridge:312-327.

Wielemans, W 2000. Ingewikkelde ontwikkeling. Opvoeding en onderwijs in relatie tot Maatschappij en Cultuur. Leuven/Leusden: Acco.

Wielemans, W \& Verhoeven, J L 1993. Market impact and policy drift: Belgian higher education, in Neave, G \& Van Vught, F A Prometheus bound. The changing relationship between government and higher education in Western Europe. Oxford: Pergamon. 